\title{
DEBATOPLAEG II
}

\section{DEN „ONTOLOGISKE VENDINGS“ UTILSTRAEKKELIGHED}

\author{
Imod udsagnet
}

\author{
CHRISTIAN K. HØJBJERG
}

Da jeg i sin tid modtog invitationen til at deltage i denne debat og blev bedt om at tage stilling for eller imod udsagnet „vi bebor mangfoldige verdener“, faldt mit valg ganske spontant og uden videre eftertanke på den sidste mulighed. $\mathrm{Og}$ det endnu uden at have gennemtænkt hele spektret af mulige udlægninger eller definitioner af udsagnet. Man kunne så spørge, om min reaktion var et udslag af det, de fleste lægfolk og ikke-antropologiske videnskabsfolk sikkert vil betegne som almindelig sund fornuft, eller om min intuitive modstand mod forestillingen om, at „,vi“, mennesket, lever i forskellige verdener, i bund og grund var en følge af mange års skoling i antropologisk teori, betragtelig feltarbejdserfaring, vidensformidling og tværvidenskabeligt samarbejde. Det har givet været lidt af det hele fra den samlede pakke af intuitiv opfattelse og faglig erfaring, der gjorde forskellen. Det kan på sin side heller ikke udelukkes, at der lå en vis portion idiosynkrasi bag valget. Jeg kunne i virkeligheden uden større vanskelighed have valgt at argumentere for det modsatte synspunkt. Som de fleste tilstedeværende vil vide, kan en rummelig definition af ideen om, at „,vi bebor mangfoldige verdener“, med god ret siges at have haft en konstituerende betydning for dannelsen af antropologien som videnskabelig disciplin. Denne definition vender jeg tilbage til om et øjeblik.

Da tidsfristen for eftertanke nærmede sig, stod det mig imidlertid klart, at min betænkelighed ved udsagnet ,vi bebor mangfoldige verdener“ ikke umiddelbart drejer sig om epistemologi eller måske ovenikøbet ontologi, men først og fremmest har en etisk begrundelse. I forbindelse med et undervisningsforløb på Københavns Universitet for et par år siden om voldelig politisk konflikt indgik der i pensum en tekst, som jeg fandt var en tankevækkende antropologisk analyse af anvendelsen af ekstrem vold under den nu afsluttede borgerkrig i Sierra Leone i Vestafrika. De studerendes reaktion på denne analyse kom delvis bag på mig. Jeg måtte med en vis overraskelse konstatere, at flere af kursusdeltagerne gav 
udtryk for indignation og vrede over resultatet af en særlig type antropologisk forskning i forhold, der passende kan beskrives som menneskelig adfærd af helt usædvanlig karakter. Denne oplevelse satte nogle spor, som dagens debatemne gav mig anledning til at genoptegne og tænke nærmere over.

\section{Radikal og moderat kulturrelativisme}

Udsagnet, at mennesket („,vi“) bebor mangfoldige verdener, kunne for så vidt være udtryk for en æstetisk anskuelsesform og ville virke som en tankevækkende titel for en udstilling om nutidskunst. Men som videnskabeligt aksiom er udsagnet uadskilleligt knyttet til den antropologiske videnskab, hvis tilblivelse hænger sammen med opdagelsen og erobringen af nye, oversøiske verdener fra det 15. århundrede og fremefter. En videnskab, der sidenhen gjorde det til sit mantra at studere forskelligheden i menneskers levevis og tankesæt i såvel tid som rum. „Vi bebor mangfoldige verdener" er et relativt udsagn, der kan udlægges på to måder, som man kan betegne som henholdsvis moderat og radikal relativisme. Den moderate variant forudsætter, at mennesket eller menneskeheden lever i én og samme verden, som man til gengæld opfatter på forskellig vis, afhængigt af den tid og den kultur, man nu en gang er en del af. Den radikale relativisme ser derimod verden som sammensat af helt igennem særegne kulturelle levemåder og tænkemåder, der ikke kan nedbringes til nogen mindste fællesnævner eller henføres til nogen som helst anden form for generaliserende, ekstern referent.

De to relativismer har dybe rødder i den antropologiske faghistorie. Man kan se dem som udtryk for antropologiens to dominerende vidensparadigmer. Den moderate relativisme indskriver sig $\mathrm{i}$ den engelske og franske oplysningstradition i det 17.-18. århundrede. Dette paradigme har ikke som et mål i sig selv at studere og formidle viden om kulturel forskellighed, men opfatter anerkendelsen af forskellighed som afsæt for en komparativ forståelse af den samlede menneskeheds sociale, kulturelle og intellektuelle udviklingsmønstre og udviklingsmuligheder. Til grund for dette projekt, der anerkender, at mennesket overalt i verden og til alle tider har indrettet sig, organiseret sig og opfattet verden på mange forskellige måder, optræder en forestilling om, at mennesket de store variationer til trods overalt og til alle tider besidder et fælles psykologisk og neurobiologisk fundament, „The Psychic Unity of Mankind“, som en af disciplinens fædre i sin tid formulerede det (Tylor 1871). Arketypen på den anden af antropologiens store vidensparadigmer er den romantiske reaktion i anden halvdel af det 18. århundrede på oplysningstraditionens fornuftsbaserede projekt om forbedringen af menneskehedens udviklingsmuligheder. Filologen og filosoffen Herder og de øvige repræsentanter for den tyske romantisme og historicisme var ikke optaget 
af store spørgsmål om almene love for socialt og kulturelt liv eller andre former for universel menneskelighed, men fremhævede i stedet konkrete menneskelige fællesskabers egenart i såvel åndelig som materiel og øvrig kulturel henseende. Uanset om man anskuer verden som en mosaik af inkommensurable enheder eller varierende udfoldelser af den samme underliggende rationalitet, er det imidlertid fælles for begge traditioner og sidenhen for antropologien som helhed at tage afsæt i og placere fokus på kulturel forskellighed eller anderledeshed. Men hvor oplysningstraditionen repræsenterer et åbenlyst universalistisk projekt, der hviler på ideen om et fælles menneskeligt, psykisk og kognitivt grundlag, finder man $\mathrm{i}$ den romantiske tradition kimen til den radikale variant af det, vi normalt betegner som kulturrelativisme. Begge traditioner forudsætter med andre ord forestillingen om forskellige verdener på et erkendelsesmæssigt eller epistemologisk plan, mens alene den kulturrelativistiske tradition rummer muligheden af det radikale udsagn om en verden, der består af forskellige virkeligheder i ontologisk forstand.

\section{Mødet med det radikalt anderledes}

Det er på tide, at jeg vender mig mod mit egentlige ærinde i denne debat. Og det er at anskueliggøre, hvorledes ideen om radikal forskellighed stiller den antropologiske forskning over for en kombineret epistemologisk og etisk problemstilling. Til illustration af det formål skal jeg inkludere et etnografisk eksempel. Hen imod afslutningen af borgerkrigen i Sierra Leone omkring århundredeskiftet greb en af de kæmpende oprørsgrupper til en helt usædvanlig form for krigsførelse. På systematisk vis begyndte unge krigere at begå ekstremt voldelige overgreb på civilbefolkningen. Uden videre begrundelse skar man bryster og bagdele af kvinder, huggede fødder, ben, hænder og arme af både spædbørn, drenge og voksne mænd. Disse lemlæstelser og amputationer af civile i Sierra Leones landdistrikter udgør et emfatisk udtryk for den vold, som antropologen Whitehead i anden sammenhæng har beskrevet som øjeblikket, hvor enhver mening forsvinder, og det irrationelle træder frem (Whitehead 2007). De unge mænd, der begik disse overgreb, har kun undtagelsesvis været i stand til, endsige bestræbt sig på, at begrunde eller retfærdiggøre deres bestialske handlinger som meningsfulde i en større sags tjeneste. For ofrene var disse mareridtsøjeblikke endnu en meningsløs del af en mangeårig krig, man ufrivilligt var blevet en del af. I journalistiske reportager og internationale humanitære organisationers afrapporteringer har man typisk indskrænket sig til at konstatere forekomsten af det nærmest ubegribelige - altså at mennesker under visse omstændigheder er i stand til at begå ekstremt voldelige gerninger mod medmennesker uden anden hensigt end blot at sprede skræk og rædsel. 
Spørgsmålet er, hvordan man skal gribe dette fænomen an. Hvordan forklarer man ud fra en antropologisk synsvinkel unge krigeres brug af ekstrem vold mod civile, og hvilken betydning kan man eventuelt tilskrive valget af lemlæstelser og amputationer? Hvad stiller man op analytisk set i fraværet af indfødte forklaringer og over for det internationale samfunds fordømmelse af gennemført irrationel adfærd og krænkelse af menneskerettigheder? Det egentlige spørgsmål er, om denne uforklarlige og uforståelige menneskelige adfærd udgør et eksempel på det, fortalerne for den såkaldte „ontologiske vending“ $i$ antropologien ville betegne som radikal anderledeshed (fx Holbraad i Venkatesan 2010; Nielsen og Pedersen i dette nummer)? Altså den tilsyneladende meningsløse vold som et uforklarligt fænomen og epistemologisk problem, hvor den antropologiske vidensproduktion og evne til oversættelse møder sin virkelige udfordring.

\section{Begrebets udvidelse}

Som antydet indledningsvis eksisterer der allerede flere antropologiske analyser af den ekstreme kollektive vold i såvel Sierra Leone som i andre egne af Afrika og i den øvrige verden. Jeg har i denne sammenhæng valgt at fremhæve en artikel fra 2006 af den amerikanske antropolog Danny Hoffman (2006) - „Disagreement: Dissent Politics and the War in Sierra Leone“ - fordi den rejser spørgsmålet om den radikale anderledeshed, og fordi den, som allerede nævnt, stimulerede mine studerendes analytiske evner og etiske dømmekraft og således gav mig tankegods til at debattere dagens emne. I sin redegørelse for de unge krigeres meningsløse vold forholder Hoffman sig kritisk over for de analyser af volden og krigen i Sierra Leone, der anskuer de unge mænds deltagelse som apolitisk. Pladsen tillader ikke at gå i detaljer med baggrunden for denne og andre forbundne regionale krige $\mathrm{i}$ nyere tid. Det afgørende for indeværende er det analytiske greb, som Hoffman benytter sig af med henblik på at omdefinere de unge krigeres tilsyneladende irrationelle og barbariske adfærd til at være en del af et meningsfuldt politisk projekt. De unge mænd gav ikke selv nogen sammenhængende forklaring på deres voldshandlinger, ofrene forstod/forstår absolut intet, og der gives heller intet historisk eller lokalt kulturelt forlæg for systematisk udøvelse af lemlæstelser og amputationer i Sierra Leone.

Med inspiration fra den politiske filosof Jacques Rancière vælger Hoffman at omdefinere begrebet om politik med henblik på at gøre det anvendeligt til at forklare forekomsten af en usædvanlig kollektiv voldelig praksis og dermed oversætte og gøre den forståelig for udenforstående. I modsætning til den etablerede opfattelse af politik som en proces af konsensusdannelse mellem subjekter, der debatterer emner, hvorom der hersker enighed, hævder Rancière 
og med ham Hoffman, at essensen af politik først og fremmest er uenighed eller uoverensstemmelse. Herunder ikke mindst uenighed om modpartens evne til at udtrykke sig og om genstanden for den politiske uenighed. Politik drejer sig i denne optik grundlæggende om anerkendelse. Ikke blot som en bestræbelse mod at kommunikere et synspunkt eller en position, men som selve skabelsen af subjektivitet og det at blive anerkendt som et talende subjekt samt synliggørelsen af en diskurs og emnet for denne diskurs. Volden er et første skridt i retningen af politisk tale. Volden danner forudsætningen for at blive anerkendt som et fællesskab af aktører, uagtet at denne „tale“ er uforståelig eller utilgængelig for andre. Med tiden vil de tilsyneladende barbariske handlinger blive tolket, omfortolket, og nye lag af betydning føjet til. De unge krigeres vold skal således forstås som en form for politisk tale indskrevet i et ufuldendt politisk projekt.

Det var her, mine studerende reagerede. De protesterede ikke blot mod, at den filosofisk inspirerede antropolog omdefinerede, hvad man skal forstå som politik, men at begrebet netop skulle være i stand til at rumme en så fordømmende adfærd, som tilfældet var i Sierra Leone. Dette epistemologiske spørgsmål peger desuden på et etisk dilemma for så vidt, at denne form for forklaring og oversættelse af det „radikalt anderledes“ til et begreb, vi alle er fortrolige med, udgør det første skridt i retningen af en retfærdiggørelse af de uskolede, marginaliserede, udnyttede, ubemidlede og oprørte unge mænds ekstreme adfærd.

\section{Afsluttende betragtninger}

Hensigten med dette indlæg har i mindre grad været at argumentere for eller imod udsagnet „,vi bebor mangfoldige verdener“, end det har været at synliggøre de dilemmaer, der rejser sig i forbindelse med anvendelsen af den radikale kulturrelativistiske fortolkning af udsagnet, og som senest er illustreret ved fortalere for den såkaldte ,ontologiske vending“ $i$ antropologien. Eksemplet med den meningsløse vold i Sierra Leone tydeliggør en analytisk svaghed ved en videnskabelig model, der forudsætter, at „hver enkelt verden indeholder sin egen logik og meningsfuldhed"og således dikterer sin egen analyse. I epistemologisk henseende ræsonnerer en sådan tilgang ikke med de lokale opfattelser og udøvelse af vold. De ,indfødte“ ville end ikke være i stand til potentielt at genkende sig selv i en sådan analyse af voldens rationale. Rationalet er væk, vilkårligheden hersker, der er ingen udsagn og fortolkninger, der byder sig til som meningsfuld beskrivelse af den ekstreme vold. Empirien tilbyder ganske enkelt intet, hvormed man kan konstruere nye begreber til forståelse af fænomenet ekstrem vold. Som udfoldet $\mathrm{i}$ ovenstående, og understreget af mine indignerede studerende, opstår der desuden et etisk dilemma, når man forsøger at udvide eller omdefinere et velkendt begreb 
med henblik på at forstå og forklare det tilsyneladende uforklarlige. I det tilfælde, hvor der ikke eksisterer en fælles, lokal begrundelse for udøvelsen af ekstrem vold, risikerer den begrebsudvidende analyse at bidrage til en retfærdiggørelse af volden. Den relativistiske synsvinkel er en integreret del af den antropologiske videnskab, men det er en tanke værd, at den radikale version møder sin analytiske begrænsning i tilfælde, hvor etnografien er så unik og usammenlignelig, at end ikke lokalbefolkningen evner at forholde sig til den. 